\title{
Chryseobacterium aquifrigidense sp. nov., isolated from a water-cooling system
}

Correspondence

Chi Nam Seong scnu@scnu.ac.kr

\author{
Seong Chan Park, ${ }^{1}$ Mi Sun Kim, ${ }^{1}$ Keun Sik Baik, ${ }^{1}$ Eun Mi Kim, ${ }^{1,2}$ \\ Moon Soo Rhee ${ }^{3}$ and Chi Nam Seong ${ }^{1}$
}

\author{
${ }^{1}$ Department of Biology, College of Natural Sciences, Sunchon National University, Suncheon \\ 540-742, Republic of Korea \\ ${ }^{2}$ Department of Dental Hygiene, Gwangyang Health College, Gwangyang 545-703, Republic of \\ Korea \\ ${ }^{3}$ Korean Collection for Type Cultures, Korea Research Institute of Bioscience and Biotechnology, \\ Daejeon 305-600, Republic of Korea
}

\begin{abstract}
A non-motile, yellow-pigmented bacterium, designated strain $\mathrm{CW}^{\top}$, was isolated from a water-cooling system in Gwangyang, Republic of Korea. The cells were Gram-negative, catalase- and oxidase-positive, short rods. The major fatty acids were iso- $\mathrm{C}_{15: 0}(45.5 \%)$, iso- $\mathrm{C}_{17: 1} \omega 9 c(14.4 \%)$, iso- $\mathrm{C}_{17: 0} 3-\mathrm{OH}(13.0 \%)$ and summed feature 3 (comprising iso- $\mathrm{C}_{15: 0}$ $2-\mathrm{OH}$ and/or $\left.\mathrm{C}_{16: 1} \omega 7 c ; 8.8 \%\right)$. The DNA G+C content was $35.6 \mathrm{~mol} \%$. A phylogenetic tree based on 16S rRNA gene sequences showed that strain $\mathrm{CW} 9^{\top}$ formed a lineage within the genus Chryseobacterium and was closely related to Chryseobacterium gleum ATCC $35910^{\top}(98.4 \%$ sequence similarity) and Chryseobacterium indologenes ATCC $29897^{\top}$ (97.8\% sequence similarity). Phenotypic characteristics and DNA-DNA relatedness data served to distinguish strain $\mathrm{CW} 9^{\top}$ from these two species. On the basis of the evidence presented in this study, strain $\mathrm{CW}^{\top}$ represents a novel species of the genus Chryseobacterium, for which the name Chryseobacterium aquifrigidense sp. nov. is proposed. The type strain is CW9 ${ }^{\top}(=\mathrm{KCTC}$ $12894^{\top}=$ JCM $14756^{\top}$ ).
\end{abstract}

The genus Chryseobacterium (type species, Chryseobacterium gleum) was described by Vandamme et al. (1994) and, at the time of writing, comprises 20 species (http:// www.bacterio.cict.fr/c/chryseobacterium.html). Strains belonging to this genus have been found in a wide variety of environments, such as fresh water (Kim et al., 2005; Gallego et al., 2006), sewage and wastewater (Kämpfer et al., 2003; Yoon et al., 2007), soil (Shen et al., 2005; Tai et al., 2006; Weon et al., 2006), plant roots (Young et al., 2005; Park et al., 2006), clinical and veterinary samples (Yabuuchi et al., 1983; Holmes et al., 1984; Mudarris et al., 1994), marine mud (Campbell \& Williams, 1951), food products (Hugo et al., 2003; de Beer et al., 2005, 2006; Shimomura et al., 2005) and bioreactor sludge (Quan et al., 2007).

In the course of a study on the microbial diversity of a watercooling system, a yellow-pigmented bacterium, designated $\mathrm{CW} 9^{\mathrm{T}}$, was isolated and subjected to a polyphasic taxonomic investigation. This study demonstrated that strain

The GenBank/EMBL/DDBJ accession number for the 16S rRNA gene sequence of strain CW9 $^{\top}$ is EF644913.

Biolog GN2 MicroPlate results for strain $\mathrm{CW}^{\top}$ are presented in a supplementary table available with the online version of this paper.
$\mathrm{CW}^{\mathrm{T}}$ represents a novel species within the genus Chryseobacterium.

Strain $\mathrm{CW}^{\mathrm{T}}$ was isolated from a cooled water sample from an oxygen-producing plant in the Republic of Korea, using the standard dilution plating technique. Isolation was achieved using plate count agar (Difco) incubated at $25{ }^{\circ} \mathrm{C}$ for 7 days. The isolate was routinely cultured on tryptic soy agar (TSA; Difco) and the culture was suspended in aqueous glycerol $(20 \%, \mathrm{w} / \mathrm{v})$ for storage at $-80{ }^{\circ} \mathrm{C}$.

Preparation of bacterial DNA and PCR amplification and sequencing of the $16 \mathrm{~S}$ rRNA gene were carried out as described previously (Chun \& Goodfellow, 1995). The resulting sequence of strain $\mathrm{CW} 9^{\mathrm{T}}$ was aligned manually against sequences obtained from the GenBank database. Phylogenetic trees were inferred from the regions available in all sequences (positions 22-1450; Escherichia coli numbering system) using the Fitch-Margoliash (Fitch, 1971; Fitch \& Margoliash, 1967) and neighbour-joining (Saitou \& Nei, 1987) methods. Evolutionary distance matrices were generated according to Jukes \& Cantor (1969). The topology of the resulting neighbour-joining tree was evaluated by means of bootstrap analysis (Felsenstein, 1985) based on 1000 resamplings. Alignment and phylogenetic analyses were carried out using the 
jPHYDIT program and PAUP 4.0 (Swofford, 1998) as described previously (Chun et al., 2000).

Preliminary sequence comparisons with 16S rRNA gene sequences held in GenBank indicated that strain $\mathrm{CW} 9^{\mathrm{T}}$ was closely related to the genus Chryseobacterium. The newly determined sequence was then aligned manually against representatives of the genus Chryseobacterium. Strain $\mathrm{CW} 9^{\mathrm{T}}$ showed the highest 16S rRNA gene sequence similarity with respect to C. gleum ATCC $35910^{\mathrm{T}}$ (98.4\%) and Chryseobacterium indologenes ATCC $29897^{\mathrm{T}}$ $(97.8 \%)$; the sequence similarities with respect to all other species of the genus Chryseobacterium were below $96.0 \%$. The neighbour-joining analysis confirmed that strain CW9 ${ }^{\mathrm{T}}$ was phylogenetically most closely related to members of the genus Chryseobacterium (Fig. 1). The tree based on the Fitch-Margoliash method showed essentially the same topology (data not shown).

Bacterial growth was tested on nutrient agar (NA; Difco), TSA, R2A agar (Difco), marine agar 2216 (Difco), cetrimide agar and MacConkey agar (Difco). Motility was examined in wet mounts using phase-contrast microscopy (TMS-F; Nikon) on cells grown in tryptic soy broth (Becton Dickinson) for 3 days at $25{ }^{\circ} \mathrm{C}$. The growth temperature $\left(4-42{ }^{\circ} \mathrm{C}\right), \mathrm{pH}(\mathrm{pH} 4-12)$ range and $\mathrm{NaCl}$ tolerance $(0,1,2,3,5,10 \%, \mathrm{w} / \mathrm{v})$ were determined on TSA after incubation for up to 1 week. Catalase and oxidase activities were determined using $3 \%(\mathrm{v} / \mathrm{v})$ hydrogen peroxide and Kovács reagent (Kovács, 1956), respectively. Acid production from sugars was tested as described by Yamaguchi \& Yokoe (2000). Nitrate reduction was tested in nitrate broth containing $0.2 \% \mathrm{KNO}_{3}$ (Skerman, 1967). Citrate utilization was tested on Simmons' citrate agar (Sigma). Indole production was determined with Kovács indole reagent in $1 \%$ tryptone broth. $\mathrm{H}_{2} \mathrm{~S}$ production was determined on Kligler's iron agar (Difco). L-Phenylalanine deamination was examined according to the method of Richard \& Kiredjian (1995). Urease activity was tested on Christensen's medium (Oxoid). Hydrolysis of casein, starch and L-tyrosine was examined on NA containing $2 \%$ skim milk, $0.2 \%$ soluble starch and $0.5 \%$ L-tyrosine (Barrow \& Feltham, 1993), respectively. Precipitation on egg yolk was determined on NA containing $10 \%$ egg yolk (Barrow \& Feltham, 1993). The pigment absorption spectrum between 250 and $700 \mathrm{~nm}$ was analysed by using an Ultrospec 2100 pro UV/visible spectrophotometer (Amersham Biosciences) following ethanol extraction of the pigments (Gosink et al., 1998) from cells grown on TSA for 3 days at $25{ }^{\circ} \mathrm{C}$. The presence of flexirubin-type pigments was investigated using the $\mathrm{KOH}$ test as described by Bernardet et al. (2002). Antibiotic resistance was determined with the disc diffusion method (NCCLS, 2003) on TSA incubated for up to 3 days at $25^{\circ} \mathrm{C}$.

Additional physiological and biochemical tests were performed using the API 20E, API 20NE, API $50 \mathrm{CH}$ and API ZYM systems (bioMérieux) and the GN2 MicroPlate (Biolog) according to the manufacturers' instructions.

Detailed results from the morphological, physiological and biochemical tests are given in the species description, in Table 1 and in Supplementary Table S1 (available with the online version of this paper). Pigment extracts from strain

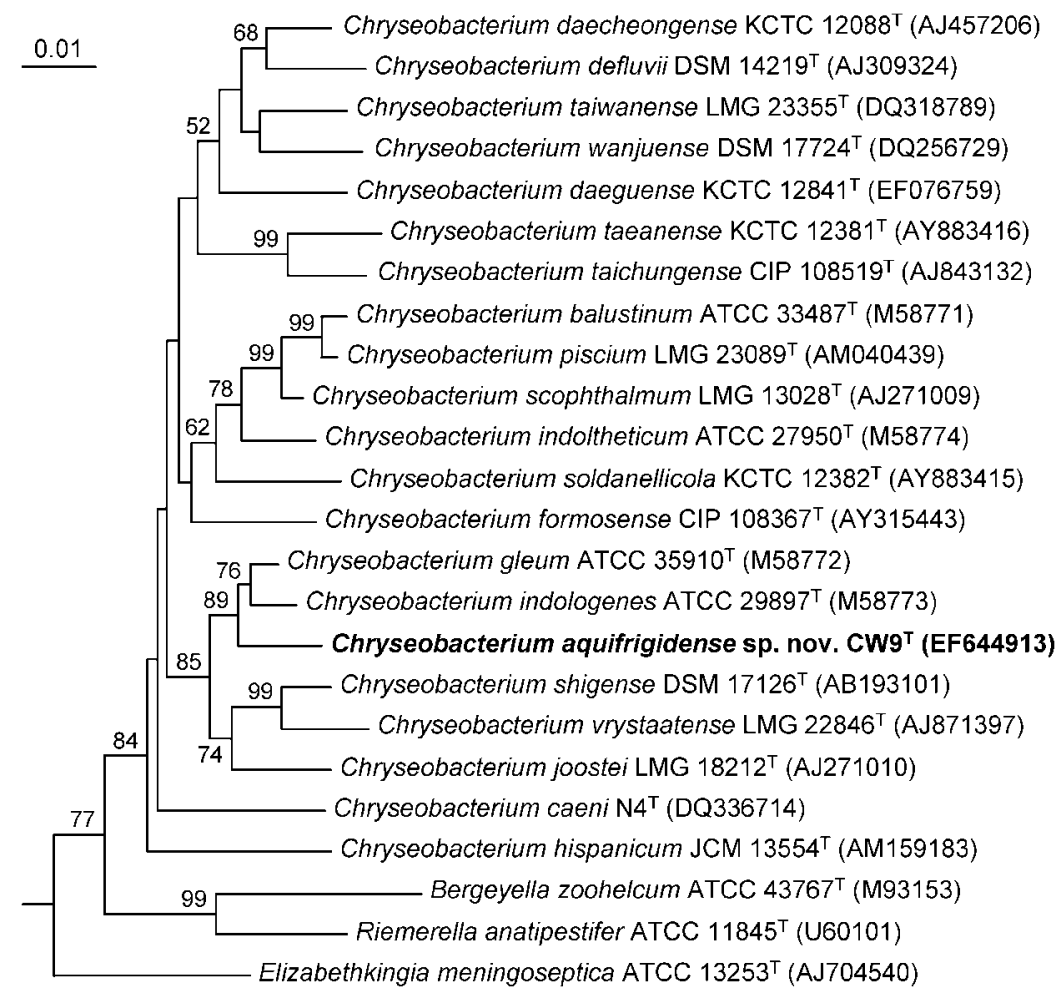

Fig. 1. Neighbour-joining phylogenetic tree, based on almost-complete 16S rRNA gene sequences, showing the relationships between strain $\mathrm{CW}^{\top}$, other members of the genus Chryseobacterium and representatives of related taxa. Bootstrap percentages (based on 1000 resampled datasets) are shown at the nodes (when $>50 \%$ ). The sequence of Ornithobacterium rhinotracheale LMG $9086^{\top}$ (GenBank accession no. L19156) was used as an outgroup (not shown). Bar, 0.01 nucleotide substitutions per position. 
$\mathrm{CW} 9^{\mathrm{T}}$ showed an absorption maximum at $454 \mathrm{~nm}$. The addition of alkali changed the colour of the pigment to red and also broadened the peak, confirming that it was a flexirubin-type pigment (Weeks, 1981).

Table 1 lists the phenotypic characteristics that clearly differentiate strain $\mathrm{CW}^{\mathrm{T}}$ from its phylogenetic neighbours, C. gleum and C. indologenes, and from other related Chryseobacterium species.

Cellular fatty acids from strain $\mathrm{CW} 9^{\mathrm{T}}$ grown on TSA for 2 days at $25{ }^{\circ} \mathrm{C}$ were prepared and analysed by GLC according to the instructions of the Microbial Identification System (MIDI, 1999). The detailed cellular fatty acid profile is given in Table 2. The DNA G+C content of strain $\mathrm{CW}{ }^{\mathrm{T}}$ was $35.6 \mathrm{~mol} \%$, as determined by using the thermal denaturation method of Marmur \& Doty (1962).

The taxonomic relationship between strain $\mathrm{CW} 9^{\mathrm{T}}, C$. gleum ATCC $35910^{\mathrm{T}}$ and C. indologenes ATCC $29897^{\mathrm{T}}$ was further examined by using DNA-DNA hybridization with

Table 1. Characteristics that differentiate strain $\mathrm{CW}^{\top}$ from closely related Chryseobacterium species

Strains: 1, CW9 ${ }^{\mathrm{T}} ; 2$, C. gleum NCTC $11432^{\mathrm{T}} ; 3$, C. indologenes GIFU $1347^{\mathrm{T}}$; 4, Chryseobacterium joostei LMG $18212^{\mathrm{T}} ; 5$, Chryseobacterium shigense $\mathrm{NCIMB} 14047^{\mathrm{T}} ; 6$, Chryseobacterium vrystaatense LMG $22846^{\mathrm{T}}$. Data are from Yabuuchi et al. (1983), Holmes et al. (1984), Hugo et al. (2003), de Beer et al. (2005) and Shimomura et al. (2005). + , Positive; - , negative; NA, data not available.

\begin{tabular}{|c|c|c|c|c|c|c|}
\hline Characteristic & 1 & 2 & 3 & 4 & 5 & 6 \\
\hline \multicolumn{7}{|l|}{ Growth at/on: } \\
\hline $5{ }^{\circ} \mathrm{C}$ & - & - & - & + & + & + \\
\hline $42{ }^{\circ} \mathrm{C}$ & - & - & + & - & - & - \\
\hline Cetrimide agar & - & - & + & + & NA & + \\
\hline MacConkey agar & - & + & + & + & - & - \\
\hline Starch hydrolysis & + & + & + & + & + & - \\
\hline \multicolumn{7}{|l|}{ Acid production from } \\
\hline \multicolumn{7}{|l|}{ Production of: } \\
\hline Indole & - & + & + & + & + & + \\
\hline $\mathrm{H}_{2} \mathrm{~S}$ & - & - & - & - & - & + \\
\hline \multicolumn{7}{|l|}{ Reduction of: } \\
\hline Nitrate & + & + & - & - & - & - \\
\hline Nitrite & + & + & - & - & NA & + \\
\hline Urease activity & - & - & - & + & - & + \\
\hline \multicolumn{7}{|l|}{ Utilization of (API $50 \mathrm{CH}$ ): } \\
\hline Trehalose & - & + & + & + & - & NA \\
\hline D-Xylose & - & + & - & - & - & - \\
\hline \multicolumn{7}{|c|}{ Enzyme activities (API ZYM): } \\
\hline Cystine arylamidase & - & - & + & + & NA & NA \\
\hline Trypsin & - & - & - & + & $\mathrm{NA}$ & NA \\
\hline$\alpha$-Chymotrypsin & - & - & + & - & NA & NA \\
\hline$\alpha$-Glucosidase & - & + & + & + & $\mathrm{NA}$ & NA \\
\hline$\beta$-Glucosidase & - & + & - & - & $\mathrm{NA}$ & NA \\
\hline DNA G $+\mathrm{C}$ content $(\mathrm{mol} \%)$ & 35.6 & 38.0 & 38.5 & 36.8 & 36.6 & 37.1 \\
\hline
\end{tabular}

a membrane filter technique, as described by Baik et al. (2006). Strain $\mathrm{CW}^{\mathrm{T}}$ shared 39 and $17 \%$ DNA-DNA relatedness with C. gleum ATCC $35910^{\mathrm{T}}$ and C. indologenes ATCC $29897^{\mathrm{T}}$, respectively, demonstrating that it represents a novel species of the genus Chryseobacterium (Wayne et al., 1987), for which the name Chryseobacterium aquifrigidense sp. nov. is proposed. A number of phenotypic characteristics clearly distinguish the novel species from the other Chryseobacterium species (Tables 1 and 2).

\section{Description of Chryseobacterium aquifrigidense sp. nov.}

Chryseobacterium aquifrigidense (a.qui.fri.gi.den'se. L. fem. n. aqua water; L. adj. frigidus cold, cool, chilled; L. suff. -ensis - is - $e$ suffixes used in the sense of 'belonging to' or 'coming from'; N.L. neut. adj. aquifrigidense pertaining to cold water, as the strains were isolated from a watercooling system).

Cells are Gram-negative, non-motile, aerobic rods 0.7$0.8 \mu \mathrm{m}$ in diameter and $1.5-2.0 \mu \mathrm{m}$ in length. Good growth occurs on TSA, NA, plate count agar and R2A agar. No growth occurs on marine agar 2216, cetrimide agar or MacConkey agar. Colonies on TSA are convex, circular, smooth, opaque with entire margins, dark yellow in colour and approximately $3 \mathrm{~mm}$ in diameter after 3 days at $25{ }^{\circ} \mathrm{C}(\mathrm{pH} 7)$. Growth occurs in the presence of 0-2\% (w/v) $\mathrm{NaCl}$ (optimum, 0\%), at $\mathrm{pH}$ 6-9 (optimum, $\mathrm{pH}$ 7) and at $15-37^{\circ} \mathrm{C}$ (optimum, $25^{\circ} \mathrm{C}$ ). Oxidase and catalase activities are present, but arginine dihydrolase, lysine decarboxylase, ornithine decarboxylase, tryptophan deaminase, $\beta$-galactosidase and $\mathrm{L}$-phenylalanine deaminase activities are absent. Casein and starch are hydrolysed, but tyrosine is not. Citrate is not utilized. Flexirubin-type pigments are produced. Acid is produced from $0.5 \%(\mathrm{w} / \mathrm{v})$ D-glucose and maltose. No precipitate is formed on eggyolk agar. Aesculin and gelatin are hydrolysed (API 20NE). None of the substrates in the API $50 \mathrm{CH}$ gallery, except glucose, maltose and aesculin, is utilized as a sole carbon and energy source. In the API ZYM gallery, alkaline phosphatase, acid phosphatase, esterase lipase (C8), leucine arylamidase, valine arylamidase, naphthol-AS-BI-phosphohydrolase and $N$-acetyl- $\beta$-glucosaminidase activities are present, but esterase (C4), lipase (C14), cystine arylamidase, trypsin, $\alpha$-chymotrypsin, $\alpha$-galactosidase, $\beta$-galactosidase, $\beta$-glucuronidase, $\alpha$-glucosidase, $\beta$-glucosidase, $\alpha$ mannosidase and $\alpha$-fucosidase activities are absent. Cells are sensitive to ( $\mu \mathrm{g}$ per disc, unless otherwise indicated) amikacin (30), chloramphenicol (30), nalidixic acid (30), streptomycin (10), tetracycline (30) and vancomycin (30), but resistant to ampicillin (10), erythromycin (15), kanamycin (30), penicillin (10 U) and polymyxin B $(300 \mathrm{U})$. The major fatty acids are iso- $\mathrm{C}_{15: 0}(45.5 \%)$, iso- $\mathrm{C}_{17: 1} \omega 9 c \quad(14.4 \%)$, iso- $\mathrm{C}_{17: 0} \quad 3-\mathrm{OH} \quad(13.0 \%)$ and summed feature 3 (comprising iso- $\mathrm{C}_{15: 0} 2-\mathrm{OH}$ and/or $\left.\mathrm{C}_{16: 1} \omega 7 c ; 8.8 \%\right)$. The complete fatty acid content is given in Table 2. The DNA G $+\mathrm{C}$ content is $35.6 \mathrm{~mol} \%$. Other physiological and biochemical characteristics are given in 
Table 2. Fatty acid content (\%) of strain $\mathrm{CW}^{\top}$ and closely related Chryseobacterium species

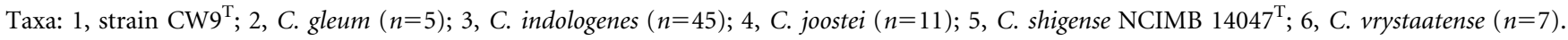
Data are from Yabuuchi et al. (1983), Hugo et al. (2003), de Beer et al. (2005) and Shimomura et al. (2005). Some of the species included were grown under different culture conditions. tr, $<1.0 \%$; NA, data not available.

\begin{tabular}{|c|c|c|c|c|c|c|}
\hline Fatty acid & 1 & 2 & 3 & 4 & 5 & 6 \\
\hline iso- $\mathrm{C}_{13: 0}$ & 1.1 & $\operatorname{tr}$ & $\operatorname{tr}$ & $\operatorname{tr}$ & $\mathrm{NA}$ & $1.1 \pm 0.4$ \\
\hline ECL $13.565^{\star}$ & $\operatorname{tr}$ & $1.2 \pm 0.4$ & $2.1 \pm 0.7$ & $1.1 \pm 0.2$ & $\mathrm{NA}$ & $1.4 \pm 0.3$ \\
\hline anteiso- $\mathrm{C}_{15: 0}$ & 1.1 & $\operatorname{tr}$ & $\operatorname{tr}$ & $\operatorname{tr}$ & NA & $1.7 \pm 0.7$ \\
\hline iso- $\mathrm{C}_{15: 0}$ & 45.5 & $35.4 \pm 2.9$ & $34.3 \pm 4.9$ & $34.6 \pm 2.0$ & 39.7 & $41.8 \pm 1.4$ \\
\hline iso- $\mathrm{C}_{15: 0} 3-\mathrm{OH}$ & 2.6 & $2.5 \pm 0.1$ & $2.6 \pm 0.2$ & $2.9 \pm 0.3$ & NA & $2.7 \pm 0.3$ \\
\hline $\mathrm{C}_{16: 0}$ & 1.8 & $1.3 \pm 0.4$ & $\operatorname{tr}$ & $\operatorname{tr}$ & $\mathrm{NA}$ & $1.1 \pm .0 .3$ \\
\hline $\mathrm{C}_{16: 0} 3-\mathrm{OH}$ & 1.6 & $1.1 \pm 0.1$ & $1.0 \pm 0.2$ & $1.2 \pm 0.2$ & $\mathrm{NA}$ & $1.3 \pm 0.3$ \\
\hline ECL $16.582^{*}$ & $\operatorname{tr}$ & $1.7 \pm 0.1$ & $1.7 \pm 0.2$ & $1.6 \pm 0.1$ & NA & $1.2 \pm 0.2$ \\
\hline iso- $\mathrm{C}_{17: 0}$ & 1.5 & $1.6 \pm 0.6$ & $\operatorname{tr}$ & $\operatorname{tr}$ & NA & $\operatorname{tr}$ \\
\hline iso- $\mathrm{C}_{17: 0} 3-\mathrm{OH}$ & 12.9 & $21.8 \pm 0.3$ & $19.2 \pm 1.8$ & $20.1 \pm 1.2$ & 19.6 & $15.4 \pm 1.8$ \\
\hline iso- $\mathrm{C}_{17: 1} \omega 9 c$ & 14.4 & $20.2 \pm 3.9$ & $24.2 \pm 3.1$ & $22.9 \pm 1.9$ & $\mathrm{NA}$ & $19.7 \pm 2.3$ \\
\hline Summed feature $3 \dagger$ & 8.8 & $11.8 \pm 0.8$ & $11.1 \pm 1.3$ & $12.1 \pm 1.3$ & NA & $9.1 \pm 0.9$ \\
\hline Summed feature $4 \dagger$ & 3 & $\operatorname{tr}$ & $\operatorname{tr}$ & $\operatorname{tr}$ & NA & $\operatorname{tr}$ \\
\hline
\end{tabular}

${ }^{\star} \mathrm{ECL}$, Equivalent chain-length (i.e. the identity of the fatty acid is unknown).

$†$ Summed features represent groups of two or three fatty acids that could not be separated by GLC with the MIDI system. Summed feature 3 contained iso- $\mathrm{C}_{15: 0} 2-\mathrm{OH}$ and/or $\mathrm{C}_{16: 1} \omega 7 \mathrm{c}$. Summed feature 4 contained iso- $\mathrm{C}_{17: 1} \mathrm{I}$ and/or anteiso- $\mathrm{C}_{17: 1} \mathrm{~B}$.

Table 1 and Supplementary Table S1 (available at IJSEM Online).

The type strain, CW9 $9^{\mathrm{T}}\left(=\mathrm{KCTC} 12894^{\mathrm{T}}=\mathrm{JCM} 14756^{\mathrm{T}}\right.$ ), was isolated from a water-cooling system in Gwangyang, Republic of Korea.

\section{Acknowledgements}

This work was supported by the BK21 (the Ministry of Education and Human Resources Development), Republic of Korea. Special thanks are extended to Dr J. P. Euzéby for his recommendation concerning the nomenclature of strain $\mathrm{CW} 9^{\mathrm{T}}$.

\section{References}

Baik, K. S., Park, Y.-D., Seong, C. N., Kim, E. M., Bae, K. S. \& Chun, J. (2006). Glaciecola nitratireducens sp. nov. isolated from seawater. Int J Syst Evol Microbiol 56, 2185-2188.

Barrow, G. I. \& Feltham, R. K. A. (1993). Cowan and Steel's Manual for the Identification of Medical Bacteria, 3rd edn. Cambridge: Cambridge University Press.

Bernardet, J.-F., Nakagawa, Y. \& Holmes, B. (2002). Proposed minimal standards for describing new taxa of the family Flavobacteriaceae and emended description of the family. Int J Syst Evol Microbiol 52, 1049-1070.

Campbell, L. L. \& Williams, O. B. (1951). A study of chitindecomposing micro-organisms of marine origin. J Gen Microbiol 5, 894-905.

Chun, J. \& Goodfellow, M. (1995). A phylogenetic analysis of the genus Nocardia with 16S rRNA gene sequences. Int J Syst Bacteriol 45, 240-245.

Chun, J., Bae, K. S., Moon, E. Y., Jung, S. O., Lee, H. K. \& Kim, S. J. (2000). Nocardiopsis kunsanensis sp. nov., a moderately halophilic actinomycete isolated from a saltern. Int J Syst Evol Microbiol 50, 1909-1913.

de Beer, H., Hugo, C. J., Jooste, P. J., Willems, A., Vancanneyt, M., Coenye, T. \& Vandamme, P. (2005). Chryseobacterium vrystaatense sp. nov., isolated from raw chicken in a chicken processing plant. Int $J$ Syst Evol Microbiol 55, 2149-2153.

de Beer, H., Hugo, C. J., Jooste, P. J., Vancanneyt, M., Coenye, T. \& Vandamme, P. (2006). Chryseobacterium piscium sp. nov., isolated from fish of the South Atlantic Ocean off South Africa. Int J Syst Evol Microbiol 56, 1317-1322.

Felsenstein, J. (1985). Confidence limits on phylogenies: an approach using the bootstrap. Evolution 39, 783-791.

Fitch, W. M. (1971). Toward defining the course of evolution: minimum change for a specific tree topology. Syst Zool 20, 406-416.

Fitch, W. M. \& Margoliash, E. (1967). Construction of phylogenetic trees. Science 155, 279-284.

Gallego, V., Teresa, M., Garcia, M. T. \& Ventosa, A. (2006). Chryseobacterium hispanicum sp. nov., isolated from the drinking water distribution system of Sevilla, Spain. Int J Syst Evol Microbiol 56, 1589-1592.

Gosink, J. J., Woese, C. R. \& Staley, J. T. (1998). Polaribacter gen. nov., with three new species, $P$. irgensii sp. nov., $P$. franzmannii sp. nov. and $P$. filamentus sp. nov., gas vacuolated polar marine bacteria of the Cytophaga-Flavobacterium-Bacteroides group and reclassification of 'Flectobacillus glomeratus' as Polaribacter glomeratus comb. nov. Int J Syst Bacteriol 48, 223-235.

Holmes, B., Owen, R. J., Steigerwalt, A. G. \& Brenner, D. J. (1984). Flavobacterium gleum, a new species found in human clinical specimens. Int J Syst Bacteriol 34, 21-25.

Hugo, C. J., Segers, P., Hoste, B., Vancanneyt, M. \& Kersters, K. (2003). Chryseobacterium joostei sp. nov., isolated from the dairy environment. Int J Syst Evol Microbiol 53, 771-777.

Jukes, T. H. \& Cantor, C. R. (1969). Evolution of protein molecules. In Mammalian Protein Metabolism, vol. 3, pp. 21-132. Edited by H. N. Munro. New York: Academic Press. 
Kämpfer, P., Dreyer, U., Neef, A., Dott, W. \& Busse, H.-J. (2003). Chryseobacterium defluvii sp. nov., isolated from wastewater. Int J Syst Evol Microbiol 53, 93-97.

Kim, K. K., Bae, H. S., Schumann, P. \& Lee, S. T. (2005). Chryseobacterium daecheongense sp. nov., isolated from freshwater lake sediment. Int J Syst Evol Microbiol 55, 133-138.

Kovács, N. (1956). Identification of Pseudomonas pyocyanea by the oxidase reaction. Nature 178, 703.

Marmur, J. \& Doty, P. (1962). Determination of the base composition of deoxyribonucleic acid from its thermal denaturation temperature. J Mol Biol 5, 109-118.

MIDI (1999). Sherlock Microbial Identification System Operating Manual, version 3.0. Newark, DE: MIDI, Inc.

Mudarris, M., Austin, B., Segers, P., Vancanneyt, M., Hoste, B. \& Bernardet, J.-F. (1994). Flavobacterium scophthalmum sp. nov., a pathogen of turbot (Scophthalmus maximus L.). Int J Syst Bacteriol 44, 447-453.

NCCLS (2003). Performance Standards for Antimicrobial Disk Susceptibility Tests, 8th edn. Approved Standard, M2-A8. Wayne, PA: National Committee for Clinical Laboratory Standards.

Park, M. S., Jung, S. R., Lee, K. H., Lee, M.-S., Do, J. O., Kim, S. B. \& Bae, K. S. (2006). Chryseobacterium soldanellicola sp. nov. and Chryseobacterium taeanense sp. nov., isolated from roots of sand-dune plants. Int J Syst Evol Microbiol 56, 433-438.

Quan, Z.-X., Kim, K. K., Kim, M.-K., Jin, L. \& Lee, S.-T. (2007). Chryseobacterium caeni sp. nov., isolated from bioreactor sludge. Int $J$ Syst Evol Microbiol 57, 141-145.

Richard, C. \& Kiredjian, M. (1995). Laboratory Methods for the Identification of Strictly Aerobic Gram-negative Bacilli. Paris: Institut Pasteur.

Saitou, N. \& Nei, M. (1987). The neighbor-joining method: a new method for reconstructing phylogenetic trees. Mol Biol Evol 4, 406-425.

Shen, F. T., Kämpfer, P., Young, C. C., Lai, W. A. \& Arun, A. B. (2005). Chryseobacterium taichungense sp. nov., isolated from contaminated soil. Int J Syst Evol Microbiol 55, 1301-1304.

Shimomura, K., Kaji, S. \& Hiraishi, A. (2005). Chryseobacterium shigense sp. nov., a yellow-pigmented, aerobic bacterium isolated from a lactic acid beverage. Int J Syst Evol Microbiol 55, 1903-1906.

Skerman, V. B. D. (1967). A Guide to the Identification of the Genera of Bacteria, 2nd edn. Baltimore: Williams \& Wilkins.
Swofford, D. L. (1998). PAUP: phylogenetic analysis using parsimony, version 4. Sunderland, MA: Sinauer Associates.

Tai, C.-J., Kuo, H.-P., Lee, F.-L., Che, H.-K., Yokota, A. \& Lo, C.-C. (2006). Chryseobacterium taiwanense sp. nov., isolated from soil in Taiwan. Int J Syst Evol Microbiol 56, 1771-1776.

Vandamme, P., Bernardet, J.-F., Segers, P., Kersters, K. \& Holmes, B. (1994). New perspectives in the classification of the flavobacteria: description of Chryseobacterium gen. nov., Bergeyella gen. nov., and Empedobacter nom. rev. Int J Syst Bacteriol 44, 827-831.

Wayne, L. G., Brenner, D. J., Colwell, R. R., Grimont, P. A. D., Kandler, O., Krichevsky, M. I., Moore, L. H., Moore, W. E. C., Murray, R. G. E. \& other authors (1987). International Committee on Systematic Bacteriology. Report of the ad hoc committee on reconciliation of approaches to bacterial systematics. Int J Syst Bacteriol 37, 463-464.

Weeks, O. B. (1981). Preliminary studies of the pigments of Flavobacterium breve NCTC 11099 and Flavobacterium odoratum NCTC 11036. In The Flavobacterium-Cytophaga Group, pp. 109-114. Edited by H. Reichenbach \& O. B. Weeks. Weinheim: Gesellschaft für Biotechnologische Forschung.

Weon, H. Y., Kim, B.-Y., Yoo, S.-H., Kwon, S.-W., Cho, Y.-H., Go, S. J. \& Stackebrandt, E. (2006). Chryseobacterium wanjuense sp. nov., isolated from greenhouse soil in Korea. Int J Syst Evol Microbiol 56, 1501-1504.

Yabuuchi, E., Kaneko, T., Yano, I., Moss, C. W. \& Miyoshi, N. (1983). Sphingobacterium gen. nov., Sphingobacterium spiritivorum comb. nov., Sphingobacterium multivorum comb. nov., Sphingobacterium mizutae sp. nov., and Flavobacterium indologenes sp. nov.: glucose nonfermenting Gram-negative rods in CDC groups IIK-2 and IIb. Int J Syst Bacteriol 33, 580-598.

Yamaguchi, S. \& Yokoe, M. (2000). A novel protein-deamidating enzyme from Chryseobacterium proteolyticum sp. nov., a newly isolated bacterium from soil. Appl Environ Microbiol 66, 3337-3343.

Yoon, J.-H., Kang, S.-J. \& Oh, T.-K. (2007). Chryseobacterium daeguense sp. nov., isolated from wastewater of a textile dye works. Int J Syst Evol Microbiol 57, 1355-1359.

Young, C. C., Kämpfer, P., Shen, F. T., Lai, W. A. \& Arun, A. B. (2005). Chryseobacterium formosense sp. nov., isolated from the rhizosphere of Lactuca sativa L. (garden lettuce). Int J Syst Evol Microbiol 55, $423-426$. 